\title{
Telomerase activity and in situ telomerase RNA expression in malignant and non-malignant lymph nodes
}

K Yashima, M A Piatyszek, H M Saboorian, A K Virmani, D Brown, J W Shay, A F Gazdar
Hamon Centre for

Therapeutic Oncology

Research, University

of Texas Southwestern

Medical Centre,

Dallas, Texas, USA

K Yashima

A K Virmani

A F Gazdar

Department of Cell

Biology and

Neuroscience

M A Piatyszek

J W Shay

Department of

Pathology

H M Saboorian

A K Virmani

A F Gazdar

Department of

Molecular Biology and

Oncology

D Brown

Correspondence to: Dr Adi F Gazdar, Hamon Centre for Therapeutic Oncology Research, UT Southwestern Medical Centre, 5323 Harry Hines Blvd., Dallas, TX, USA 75235-8593.

e-mail:

gazdar $($ simmons.swmed.edu

Accepted for publication 17 December 1996
Aims/background-Telomerase, an en-
zyme associated with cellular immortal-
ity, is expressed by most malignant zyme associated with cellular immortal-
ity, is expressed by most malignant
tumours, but is inactive in normal sotumours, but is inactive in normal soproliferating stem cells. Thus, the
measurement of telomerase activity in tis-
sue samples may provide useful diagnostic sue samples may provide useful diagnostic and prognostic information. The aim of
this study was to determine whether
telomerase expression is useful for the telomerase expression is useful for the detection of occult malignant cells in
lymph nodes.

Methods-Telomerase activity was compared with histological findings in 123 surgically removed lymph nodes submitted for routine or frozen section diagnosis.
Telomerase activity was measured using a
modified, semi-quantitative PCR-based modified, semi-quantitative PCR-based telomeric repeat amplification protocol pared with protein concentration. Furthermore, using an in situ hybridisation method, the human telomerase RNA (hTR) component was measured in a subset of negative and positive nodes. Results-Most (96\%) of the 97 histologically negative nodes expressed low levels of activity (mean value of positive samples $=3.0$ units/ $\mu$ protein) which may be derived from activated lymphocytes that express telomerase activity. All 26 malignant nodes (17 metastases, nine lymphomas) expressed telomerase (mean value $=17.8$ units $/ \mu$ grotein). The rank order levels between the two groups differed significantly $(p=0.0002)$. In situ results showed clearly that the hTR was expressed relatively highly in metastatic cancer cells and at lower levels in germinal centres of secondary follicles.

Conclusions-Although expression of telomerase by activated lymphocytes may limit its usefulness, measurement of en- zyme activity combined with detection of hTR using in situ hybridisation may assist in the histopathological diagnosis of lymph nodes.

(f Clin Pathol 1997;50:110-117)

Keywords: telomerase; lymph nodes; in situ hybridisation.

Telomeres are specialised heterochromatic structures at the end of eukaryotic chromosomes, and are composed of simple repetitive G-rich hexameric sequences (TTAGGG in vertebrates). ${ }^{1-3}$ Telomeres are important for the stability, replication, and function of chromosomes. $^{45}$ In normal somatic cells, telomere length (the number of repeats) decreases during every cell division as a result of the inability of the lagging strand to replicate the very $5^{\prime}$ end of a linear DNA molecule. ${ }^{67}$ Progressive telomere shortening has been proposed to be the major timing mechanism that determines in vitro cellular senescence. ${ }^{8-10}$ In cells immortalised in vitro, telomere length is stabilised, probably as a result of activation of telomerase. Recent findings support the concept that activation of telomerase may be an important and obligate step in the development of most malignant tumours. Telomerase is an RNA-containing ribonucleoprotein enzyme that synthesises TTAGGG telomeric DNA repeats onto chromosomal ends de novo. ${ }^{11}{ }^{12} \mathrm{It}$ is expressed in most human cancers and immortal cell lines ${ }^{13-20}$ but is inactive in normal somatic cells except for germ cells ${ }^{14}$ and stem cells present in bone marrow, ${ }^{21}{ }^{22}$ lymphoid tissue, ${ }^{23-27}$ colonic crypts, ${ }^{28}$ and epidermis. ${ }^{29} 30$

For human telomerase, the RNA (hTR) and protein components are encoded by independent genes. The gene coding for hTR has been cloned recently. ${ }^{31}$ As the hTR is necessary for telomere elongation by telomerase, it is possible that telomerase activity may correlate with hTR expression. However, using northern blotting, it has been reported that hTR levels may not be a good predictor for the presence or amount of telomerase enzyme activity. ${ }^{32}$ 
Pathological examination of lymph nodes is crucial for the diagnosis of metastatic cancer and lymphomas. Immunohistochemical and molecular analyses permit the assessment of micrometastatic tumour cells in lymph nodes that are not detected by conventional histopathological examination. ${ }^{33-41}$ Telomerase activity is expressed in lymphomas and in tumours metastasising to lymph nodes, suggesting that it may be useful for the detection of histologically undetectable occult metastases. ${ }^{14} 162742$

A PCR-based telomeric repeat amplification protocol (TRAP) for the analysis of small tissue samples was developed, which permits a large number of tumour samples to be examined at one time. ${ }^{14}$ However, routine telomerase enzyme assays for tumour diagnosis have three potential drawbacks: (1) they are not quantitative; (2) tissue samples may contain inhibitors of Taq polymerase or other substances that interfere with the PCR-based assay ${ }^{43}{ }^{44}$; and (3) in tissue and tumour samples (which invariably consist of mixtures of cell types), the precise cell type(s) expressing telomerase cannot be identified. In an effort to address these shortcomings, we used a modified, semiquantitative PCR-based TRAP assay. ${ }^{44}$ The assay included an internal standard for the detection of Taq polymerase and other PCR inhibitors, and we developed and applied an in situ hybridisation method to detect expression of hTR. We measured the normalised telomerase activities in 123 surgically removed lymph nodes and compared the results with histopathological findings. We also measured the hTR component in a subset of the lymph node samples.

\section{Methods}

TISSUE SAMPLES

We studied telomerase expression in 123 surgically removed lymph nodes from 53 patients (38 patients with carcinoma, eight with lymphoma, one with sarcoma, and six with benign diseases) (table 1). The specimens included 91 frozen sections. Of the 123 nodes, 115 were from patients with malignant diseases and the remaining eight were from patients with benign diseases. Of the 115 nodes from patients with malignant diseases, 26 were histologically positive for metastatic tumour or lymphoma. Frozen samples were embedded in OCT (Miles Inc., Elkhart, Indiana, USA) at $-20^{\circ} \mathrm{C}$ and immediately sectioned at $5 \mu \mathrm{m}$ and stored at $-80^{\circ} \mathrm{C}$ until telomerase was extracted. Surgically resected tissues were also stored at $-80^{\circ} \mathrm{C}$. Pathological diagnoses were

Table 1 Lymph node samples used for telomerase assays

\begin{tabular}{lccc}
\hline & Patients $(n)$ & $\begin{array}{l}\text { Frozen } \\
\text { sections }(n)\end{array}$ & Surgical tissues $(n)$ \\
\hline Negative nodes & 6 & 3 & 5 \\
$\quad$ Benign disease & 28 & 68 & 21 \\
$\quad$ Malignant disease & 15 & 11 & 6 \\
Tumour-containing nodes & 8 & 9 & 0 \\
$\quad$ Metastatic carcinoma & $53^{\star}$ & 91 & 32 \\
$\quad$ Lymphoma & & & \\
Total & & & \\
\hline
\end{tabular}

^Both tumour-containing and negative nodes were obtained from four patients. made using haematoxylin and eosin stained slides of serial cryostat sections and confirmed by examination of formalin fixed, paraffin wax embedded sections of the previously frozen tissues. Telomerase results were correlated carefully with histopathological findings. The usefulness of applying the TRAP assay to frozen section samples was confirmed using five tumour samples (four breast carcinomas and one lung carcinoma).

EXTRACTION OF TELOMERASE FROM FROZEN SECTION SLIDES

OCT embedded $5 \mu \mathrm{m}$ frozen section samples were homogenised on glass slides in 25-50 $\mu \mathrm{l}$ CHAPS lysis buffer (0.5\% CHAPS, $10 \mathrm{mM}$ Tris- $\mathrm{HCl}$ (pH 7.5), $1 \mathrm{mM} \mathrm{MgCl}_{2}, 1 \mathrm{mM}$ EGTA, 15\% glycerol, $0.1 \mathrm{mM}$ AEBSF (4-(2aminoethyl)-benzensulphonyl fluoride hydrochlorine), $0.025 \mathrm{U} / \mu \mathrm{l}$ RNase inhibitor (5 Prime $\rightarrow 3$ Prime Inc., Boulder, Colorado, USA)) using a $200 \mu \mathrm{l}$ pipetman. The whole cell lysate was rapidly frozen and stored at $-80^{\circ} \mathrm{C}$. An aliquot $(2 \mu \mathrm{l})$ of the extract was used for each telomerase assay. The protein concentrations of the whole cell lysates were measured using the BCA protein assay kit (Pierce Chemical Corp., Rockford, Illinois, USA). Surgically resected tissues were extracted and analysed as described before. ${ }^{1443}$

\section{SEMI-QUANTITATIVE TRAP ASSAY}

For analysis of telomerase activity, a modified semi-quantitative TRAP assay which uses an internal telomerase assay standard (ITAS), was used as described previously. ${ }^{44}$ The necessity for an internal standard was twofold. First, extracts from certain tissue samples contain inhibitors of Taq polymerase, which may result in false negative values. Inhibitor-containing samples have diminished amplification, or in extreme cases, lack amplification of the telomerase activity ladder and the internal standard (a 150 base pair, double stranded DNA template with TS and CX target sites). Dilution of inhibitor-containing samples sometimes results in amplification of the internal standard and detection of the telomerase activity ladder, permitting accurate interpretation of the test results. Second, as described later, inclusion of the internal standard permits normalisation of enzyme activity. To each reaction mixture, $5 \times 10^{-18} \mathrm{~g}$ (5 attograms) of the internal standard was added. ${ }^{44}$ The ITAS is sufficiently long so that it does not interfere with the visualisation of the telomerase ladder. For ribonuclease (RNase) treatment, $5 \mu l$ of extract was incubated with RNase (Boehringer Mannheim Corp., Indianapolis, Indiana, USA) for 20 minutes at room temperature. The other assay conditions and the primer pair (CX and TS primers) were as described previously. ${ }^{43}$

NORMALISATION OF TELOMERASE ACTIVITY Half of the PCR products were analysed by using electrophoresis in $0.5 \times$ Tris-borate EDTA buffer on $10 \%$ polyacrylamide, nondenaturing gels. The gels were fixed in $0.5 \mathrm{M}$ $\mathrm{NaCl}, 50 \%$ ethanol and $40 \mathrm{mM}$ sodium acetate $(\mathrm{pH} 4.2)$ for 25 minutes, and next 

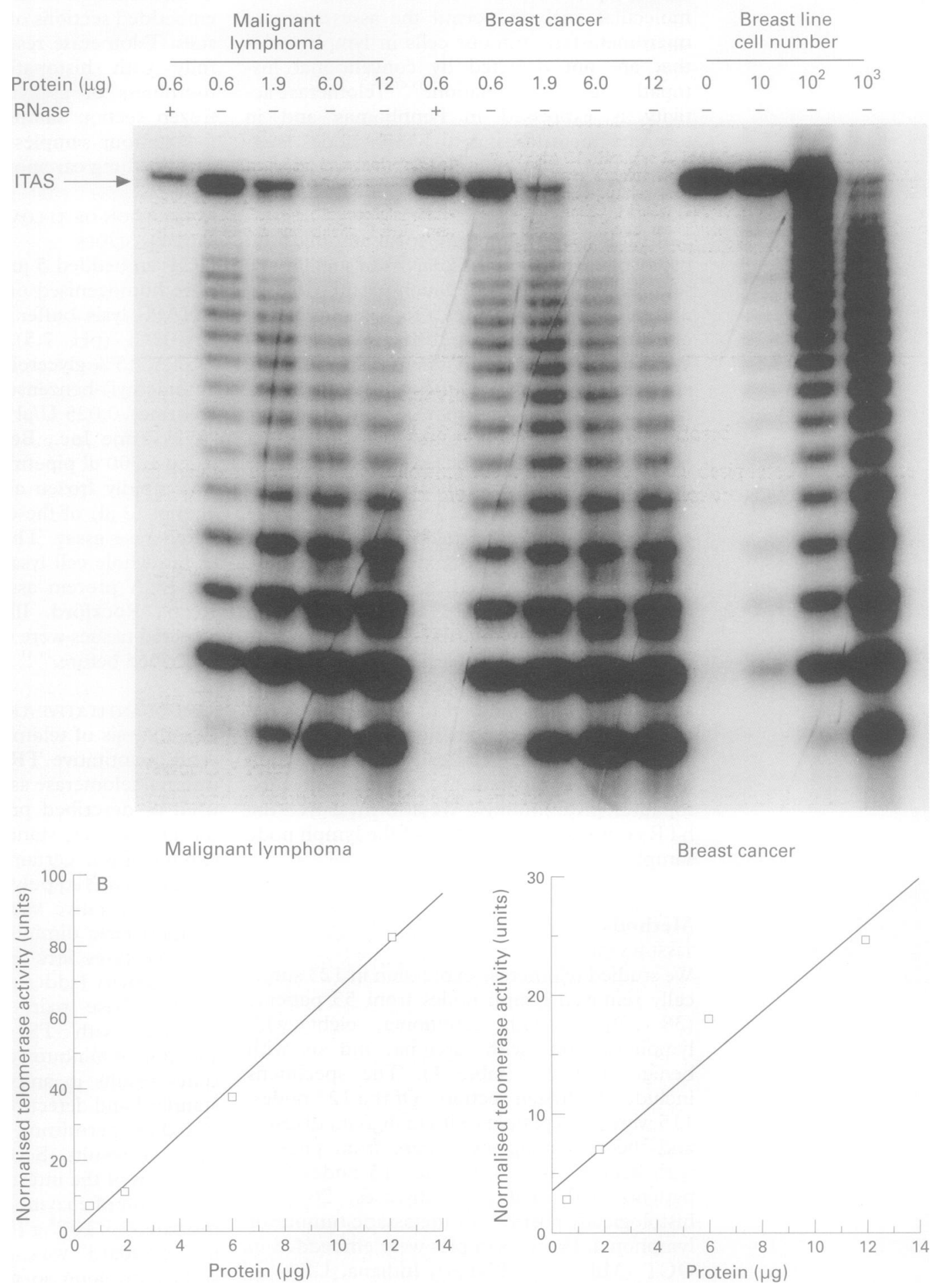

Figure 1 Normalisation of telomerase activity. (A) Varying concentrations of cell extracts of surgically resected tumours (malignant lymphoma and breast cancer) with $(+)$ or without $(-)$ ribonuclease (RNase) pretreatment were assayed in the presence of a 150 base pair ITAS internal control. For positive controls, extracts from varying cell numbers of a human breast cancer cell line were used. The lysis buffer was used as a negative control. Telomerase activity is represented by a ladder-like pattern of bands varying by 6 base pairs in size (that is, the telomeric repeat sequence TTAGGG). (B) The lanes of the two tumour samples depicted in $(A)$ were scanned and measured using a PhosphorImager. The integrated values of the telomerase ladder were normalised to that of the internal standard, and these relative ratios are depicted as units (open squares represent normalised telomerase values). The solid lines without symbols represent computer fitted curves.

exposed to phosphor screens for 12-18 hours without drying. The PCR products of the TRAP assay were visualised on a PhosphorImager (Molecular Dynamics, Sunnyvale, California, USA) using the ImageQuant software provided by the supplier. The signal intensity of the telomerase-specific 6-base repeat ladder was determined by area integration and this value was normalised to the signal obtained for the internal standard present in an analysed sample. Thus, the normalised values of telomerase activity were expressed in arbitrary units. The original description of this quantitative method used tumour cell lines. ${ }^{44}$ We have 
confirmed that tissue samples also yield linear results over at least a 20 -fold concentration range, permitting normalisation of most clinical samples (figs $1 \mathrm{~A}$ and $1 \mathrm{~B}$ ). The activity of each sample was normalised to that of $1 \mu \mathrm{g}$ of total cellular protein.

PREPARATION AND PREHYBRIDISATION OF TISSUE SECTIONS FOR IN SITU HYBRIDISATION

Paraffin wax embedded $(5 \mu \mathrm{m})$ tissue sections of six tumour negative and four tumour positive lymph nodes were cut onto Superfrost/ Plus slides (Fisher Scientific, Pittsburgh, Pennsylvania, USA). The sections were deparaffinised, rehydrated in phosphate buffered saline (PBS), and treated with proteinase $\mathrm{K}(20 \mu \mathrm{g} /$ $\mathrm{ml})$ in $50 \mathrm{mM}$ Tris- $\mathrm{HCl}(\mathrm{pH} 7.5)$ and $5 \mathrm{mM}$ EDTA for 20 minutes at room temperature. After rinsing for five minutes in PBS, sections were postfixed in $4 \%$ paraformaldehyde/PBS, rinsed in water, and acetylated in freshly prepared $0.25 \%$ acetic anhydride $/ 0.1 \mathrm{M}$ triethanolamine for 10 minutes. The slides were dehydrated in gradually increasing concentrations of ethanol prior to hybridisation.

PROBE PREPARATION FOR IN SITU HYBRIDISATION The plasmid pGEM-5Z (Promega Corp., Madison, Wisconsin, USA) containing a human telomerase RNA (hTR) complementary DNA (559 nucleotides), obtained from Geron Corp., Menlo Park, California, USA, was used as a template to generate sense and antisense probe. $\left[{ }^{35} \mathrm{~S}\right]-\mathrm{UTP}$ labelled single stranded RNA probes were synthesised as described by the manufacturer (Ambion Inc., Austin, Texas, USA). Transcripts were alkali hydrolysed to generate probes with an average length of 200 nucleotides for efficient hybridisation, purified using a G-50 column (Boehringer Mannheim), and precipitated in ethanol. The probes were resuspended in $30 \mu \mathrm{l}$ $100 \mathrm{mM}$ dithiothreitol. The specific activity of the radiolabelled probes was approximately $3 \times 10^{7} \mathrm{cpm} / \mu \mathrm{g}$ template DNA. The probes were aliquoted and stored at $-80^{\circ} \mathrm{C}$ until use.

HYBRIDISATION AND WASHING PROCEDURES

Sections were hybridised overnight at $52^{\circ} \mathrm{C}$ in $50 \%$ deionised formamide, $0.3 \mathrm{M} \mathrm{NaCl}$, $20 \mathrm{mM}$ Tris- $\mathrm{HCl}$ (pH 7.5), $5 \mathrm{mM}$ EDTA, $10 \mathrm{mM} \mathrm{NaH} \mathrm{PO}_{4}$ (pH 8.0), $10 \%$ dextran sulphate, $1 \times$ Denhardt's solution, $500 \mu \mathrm{g} / \mathrm{ml}$ total yeast RNA, $10 \mathrm{mM}$ dithiothreitol, and $50000 \mathrm{cpm} / \mu \mathrm{l}^{35} \mathrm{~S}$-labelled cRNA probe. The tissue was washed stringently at $50^{\circ} \mathrm{C}$ in $5 \times$ SSC, $10 \mathrm{mM}$ dithiothreitol for 30 minutes, at $65^{\circ} \mathrm{C}$ in $50 \%$ formamide, $2 \times \mathrm{SSC}, 10 \mathrm{mM}$ DTT for 20 minutes, and washed twice at $37^{\circ} \mathrm{C}$ in $0.4 \mathrm{M} \mathrm{NaCl}, 10 \mathrm{mM}$ Tris- $\mathrm{HCl}$ (pH 7.5), $5 \mathrm{mM}$ EDTA for 10 minutes before treatment with $20 \mu \mathrm{g} / \mathrm{ml}$ RNase A at $37^{\circ} \mathrm{C}$ for 30 minutes. Following washes in $2 \times \mathrm{SSC}$ and $0.1 \times$ SSC for 10 minutes at $37^{\circ} \mathrm{C}$, the slides were dehydrated and dipped in Kodak NTB-2 nuclear track emulsion and exposed for three weeks in light tight boxes with desiccant at $4^{\circ} \mathrm{C}$. The microautradiographs were developed in Kodak Dektol developer (three and a half minutes), washed in water (20 seconds), fixed in
Kodak fixer (seven minutes), rinsed in water, and counter-stained with haematoxylin and eosin.

\section{Results}

SEMI-QUANTITATIVE TRAP ASSAY USING PROTEIN EXTRACTS FROM FROZEN SECTIONS

In this study, we used a semi-quantitative version of the TRAP assay ${ }^{44}$ and confirmed that it can be used to analyse clinical specimens. ${ }^{29} 45$ The modified method uses a 150 base pair double stranded DNA template with TS and CX target sites as an internal standard to normalise telomerase activity and exclude false negative results owing to PCR inhibitors. ${ }^{44}$ Although the assay was linear over the range of protein concentrations used for clinical measurements, one potential problem was competition between the internal standard and the telomerase activity products for enzyme (figs $1 \mathrm{~A}$ and $1 \mathrm{~B})$. To normalise values, we used dilutions at which both the enzyme activity and the internal standard were clearly visible.

To confirm detection of telomerase activity using whole cell extracts from frozen sections, we assayed one lung cancer and four breast cancer specimens. In all five cases, comparable telomerase activity was detected in fresh frozen tumour samples and in adjacent single $5 \mu \mathrm{m}$ OCT embedded frozen sections (data not shown). These results indicate that whole cell extracts from frozen sections contain sufficient amounts of telomerase for detection using the modified TRAP assay.

\section{TELOMERASE ACTIVITY IN BENIGN AND}

MALIGNANT LYMPH NODES

We measured telomerase activity in 123 surgically resected lymph nodes, comprising 91 frozen sections and 32 fresh tissues (tables 1 and 2 ; figs 2 and 3). Laboratory results were correlated with corresponding tissues submitted for histopathological examination. All 26 malignant lymph nodes obtained from 17 tumour metastases and nine malignant lymphomas had telomerase activity (table 2). Telomerase activity was also detected in $93(96 \%)$ of 97 benign lymph nodes (table 2). In histologically negative nodes with malignancy, normalised telomerase activities were similar to those with benign conditions (table 2).

In contrast, mean values of normalised telomerase activity of histologically negative and positive nodes were 3.0 (range $0-32.9$ ) and 17.8 (range $0.04-127.8$ ) units/ $\mu$ g protein, respectively (fig 3 ). Although there was some overlap in values, the rank order level of normalised telomerase activity in positive nodes was significantly higher than that of negative nodes $(p=0.0002, n=119$, Wilcoxon rank sum test).

\section{EXPRESSION OF hTR IN NEGATIVE AND POSITIVE} LYMPH NODES

In an effort to improve the diagnostic value of telomerase measurements, we developed and applied an in situ hybridisation method to detect hTR expression in archival paraffin wax sections. The specificity of the assay was confirmed by hybridisation of the probe in the 
Table 2 Telomerase activity in tumour-containing and benign lymph nodes

\begin{tabular}{lll}
\hline & No positive/total (\%) & Mean value (range)* \\
\hline Negative nodes & $93 / 97(96)$ & $3.0(0-32.9)$ \\
Patients with malignancy & $85 / 89(96)$ & $3.0(0-32.9)$ \\
Patients without malignancy & $8 / 8(100)$ & $3.1(0.04-10.7)$ \\
Tumour-containing nodes & $26 / 26(100)$ & $17.8(0.04-127.8)$ \\
Metastatic carcinoma & $17 / 17(100)$ & $18.4(0.04-127.8)$ \\
Lymphoma & $9 / 9(100)$ & $16.7(0.2-76.2)$ \\
\hline
\end{tabular}

${ }^{\star}$ Units/ $\mu \mathrm{g}$ protein.

Table 3 Relation between hTR and telomerase enzyme activity in lymphoid tissues

\begin{tabular}{|c|c|c|c|c|}
\hline \multirow[b]{2}{*}{ Diagnosis } & \multicolumn{2}{|c|}{ Lymph node histology } & \multirow[b]{2}{*}{$\begin{array}{l}\text { Normalised telomerase } \\
\text { activity (units/ } \mu \mathrm{g})\end{array}$} & \multirow[b]{2}{*}{$\begin{array}{l}\text { hTR } \\
\text { expression }\end{array}$} \\
\hline & $\begin{array}{l}\text { Germinal } \\
\text { centres }\end{array}$ & $\begin{array}{l}\text { Metastatic } \\
\text { tumour }\end{array}$ & & \\
\hline Tuberculosis & - & - & 0.04 & - \\
\hline Prostate cancer & + & - & 4.6 & G+ \\
\hline Prostate cancer & + & - & 6.35 & $\mathrm{G}+$ \\
\hline Laryngeal cancer & + & - & 19.2 & $\mathrm{G}+$ \\
\hline Lung cancer & + & - & 16.1 & G+ \\
\hline Lung cancer & + & - & 32.9 & $\mathrm{G}+$ \\
\hline Lung cancer & - & + & 8.12 & $\mathrm{~T}+$ (weak) \\
\hline Lung cancer & - & + & 19.2 & $\mathrm{~T}+$ \\
\hline Lung cancer & + & + & 30.2 & $\mathrm{G}+, \mathrm{T}+$ \\
\hline Lung cancer & + & + & 127.8 & $\mathrm{G}+, \mathrm{T}+$ \\
\hline
\end{tabular}

Lymph nodes from a subset of 10 cases (nine from patients with cancer) were examined for normalised telomerase activity using the TRAP assay and for hTR expression using in situ hybridisation. The presence of germinal centres or metastatic tumour was noted. + , present; - , absent; $\mathrm{G}+$, hTR expression in germinal centres; $T+$, hTR expression in metastatic tumour cells.

antisense configuration (described later), and the absence of cellular localisation in sections hybridised with the probe in the sense configuration. Sections of adult testis had high hTR expression limited to the seminiferous tubules, predominantly in primary spermatocytes and, possibly, spermatogonia, whereas spermatids and spermatozoa were negative (data not shown).

We then examined lymph nodes from a subset of 10 patients for telomerase activity and hTR expression. One patient had tuberculosis, with loss of normal architecture and widespread fibrosis and necrosis. The remaining samples were from patients with cancer, four of whom had histopathologically confirmed metastases in the nodes examined. hTR was expressed in all examined lymph nodes from patients with cancer, but not in the tubercular node (which had very weak enzyme activity) (table 3, fig 4). In nodes with metastases, hTR was expressed in both tumour cells (fig 4A) and in germinal centres (fig 4B) (when present). In two tumour-containing nodes lacking secondary follicles, hTR expression was limited to the tumour cells (table 3). Expression of hTR in the tumour cells was considerably stronger than in the germinal centres (fig 4C). In five cases, metastatic tumour was not present in the nodes examined, but germinal centres (with hTR expression) were present in all five cases. Other regions of the lymph nodes (parafollicular, medullary and sinusoidal areas) either lacked hTR expression or had occasional weakly expressing cells. In all cases where subcellular localisation was possible (that is, in cells having a relatively large amount of cytoplasm), expression was predominantly or entirely nuclear.
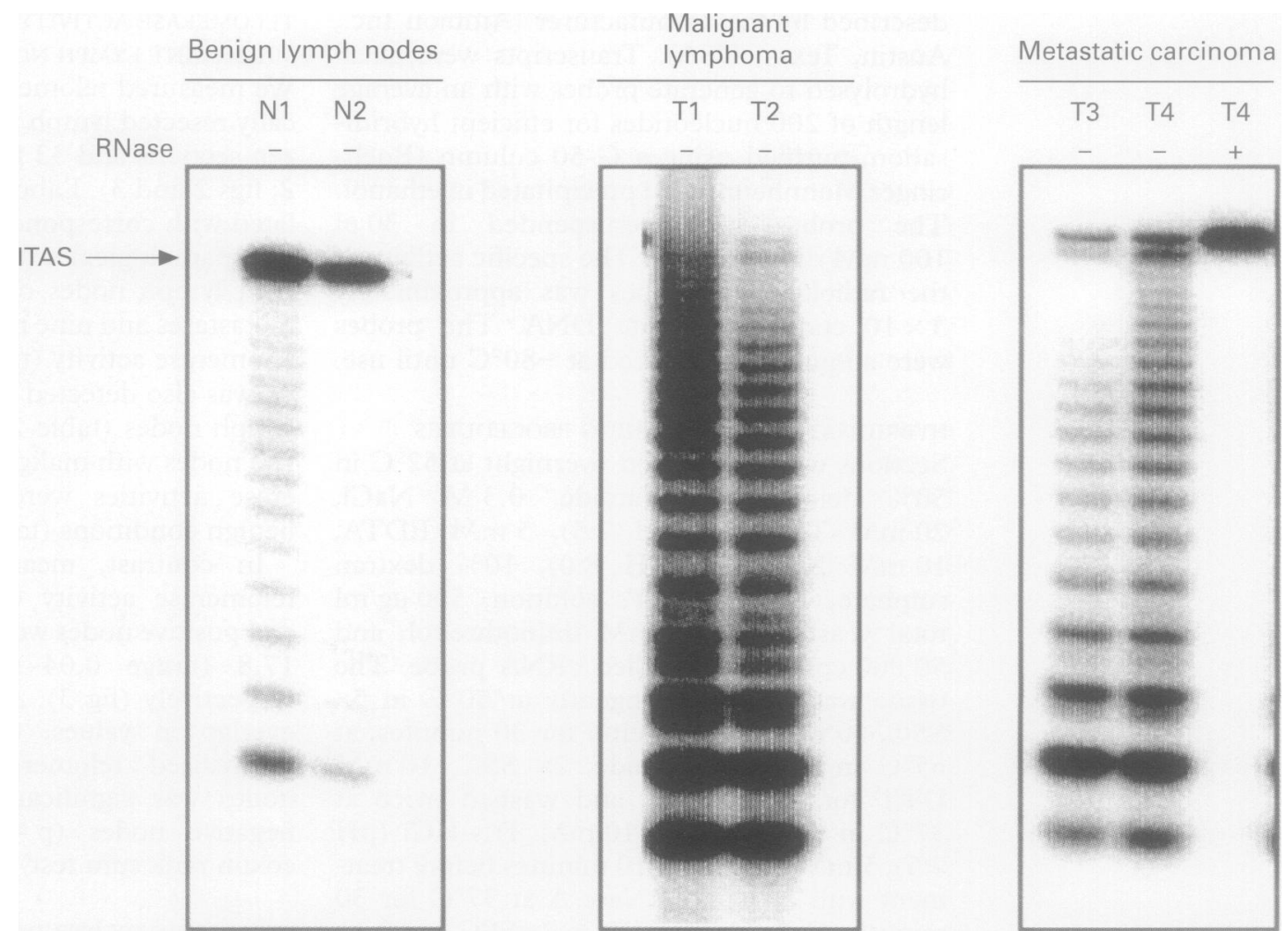

Figure 2 Telomerase activity in benign and malignant lymph nodes. Telomerase assays were performed using extracts containing $3 \mu \mathrm{g}$ of protein from an OCT embedded frozen section sample. The following representative examples of lymph nodes are illustrated: left panel: histologically negative nodes from patients with prostate cancer (N1 and N2); middle panel: non-Hodgkin's lymphoma (T1 and T2); and right panel: metastatic carcinoma (T3 is from non-small cell lung carcinoma, T4 from a vaginal carcinoma), before $(-)$ and after $(+)$ RNase treatment. All samples are positive, and the activity (in T4) is abolished by RNase treatment. Note that the normalised activity is much higher in the tumour-containing samples. The uppermost band represents the internal telomerase assay standard (ITAS) control. Note, in sample T1 the telomerase activity is so high that the internal standard is not visible (because of competition for PCR reagents). Normalisation of such samples requires dilution. 


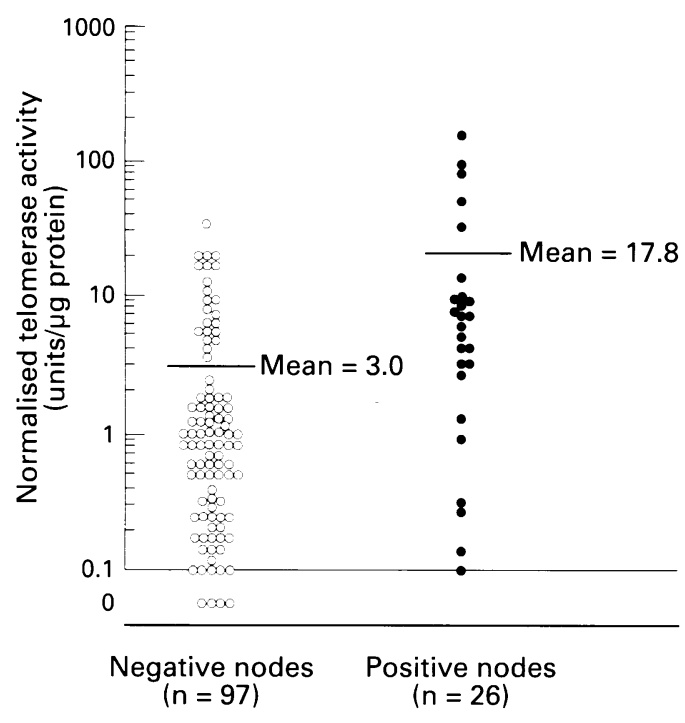

Figure 3 Comparison of normalised telomerase activities in histologically negative and positive lymph nodes. The normalised telomerase activity of each sample is presented. Except for four samples from histologically negative lymph nodes, the remaining 119 samples were positive for telomerase activity.

\section{Discussion}

Telomerase activity has been detected in a wide variety of human tumours and tumour-derived cell lines, whereas it has been rarely detected in normal cells in vitro and normal somatic tissues in vivo using the PCR-based TRAP assay for enzyme activity. ${ }^{13-20}$ Thus, the TRAP assay is an effective method for the detection of telomerase activity in clinical samples. The original published version of the TRAP assay ${ }^{14}$ did not describe methods to normalise telomerase activity nor to detect occasional false negative results owing to the presence of inhibitors.

In this study, we used an improved semiquantitative TRAP assay, which included an appropriate internal standard, the amplification of which requires the presence of Taq polymerase. ${ }^{44} \mathrm{~A}$ recently available commercial version of the assay offers an internal standard that is shorter than the telomerase ladder, and seems to be more resistant to the effects of inhibitors. ${ }^{45}$ Using both fresh tissue and frozen sections, we showed that the assay was linear over more than a 20 -fold range of protein concentrations, permitting normalisation of the values of most clinical specimens. Lack of amplification of the internal standard indicated the presence of inhibitors (usually of Taq polymerase). When inhibitors were detected, their effect, in most cases, could be alleviated by dilution of the tested extract. Moreover, to compare telomerase activity precisely with histological findings in most cases, we used protein extracts from frozen sections of the same sample used for histopathological diagnosis.

Previous studies have shown that some normal adult somatic tissues, including male germ cells, ${ }^{14} 46$ peripheral blood cells and blood stem cells, had telomerase activity. ${ }^{21-26}$ We detected telomerase activity in all 26 malignant lymph nodes. However, most of benign lymph nodes also had some detectable telomerase activity. Our findings indicate that certain lymphoid
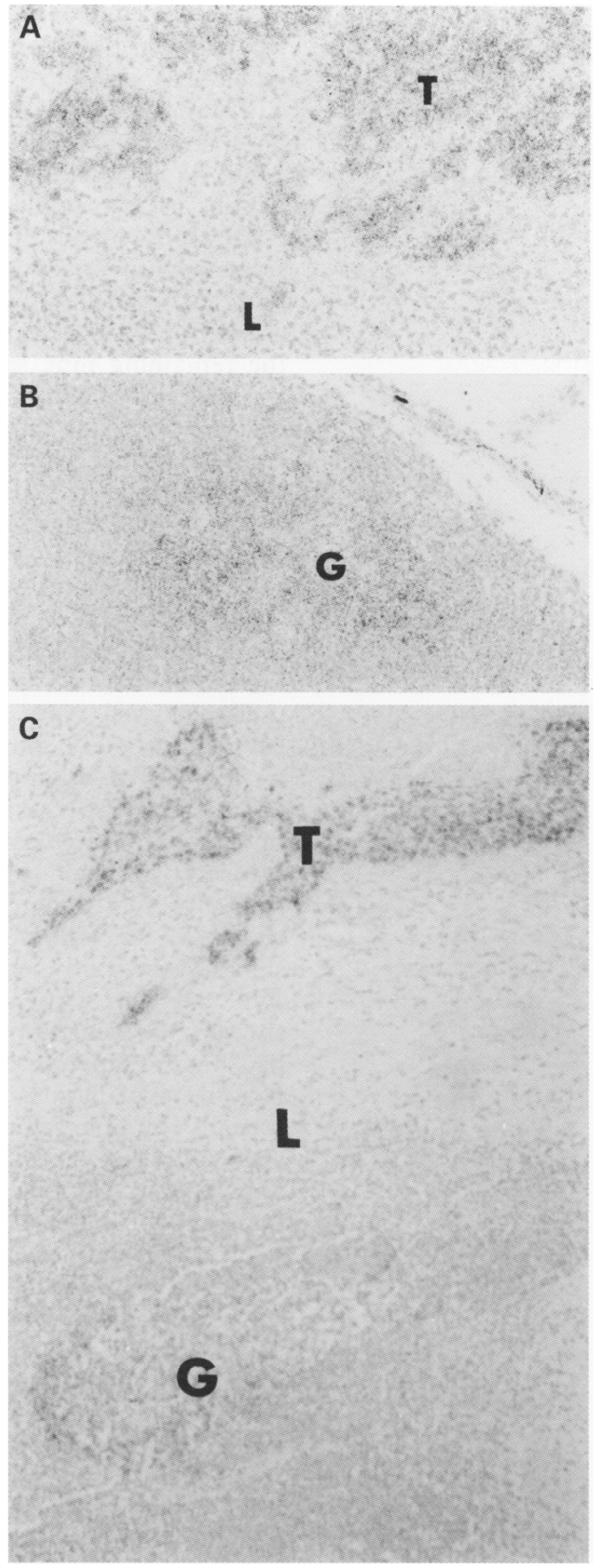

Figure 4 In situ hybridisation for $h T R$ expression in lymph nodes. $h T R$ expression was present in metastatic lung cancer cells $(A)$ and germinal centres $(B)$. In tumourcontaining nodes, $h T R$ expression in tumour cells was always greater than in germinal centres present in the same nodes $(C) . T=$ tumour cells; $L=$ lymph node; $G=$ germinal centre.

cells may express weak telomerase activity, as has also been reported by others. ${ }^{27}$ Of interest, although there was some overlap in values, the mean value of telomerase activity was approximately sixfold higher in pathologically positive malignant lymph nodes than that in lymph nodes without tumour metastases. Thus, in certain situations, measurements of normalised telomerase activity may facilitate the diagnosis of lymph node malignancy, although its value in detecting occult micrometastases remains unproven.

In an effort to improve the usefulness of measuring telomerase activity for the detection 
of occult metastases, we have developed an in situ hybridisation method to detect human telomerase RNA (hTR). We showed the specificity of the assay by examining sections of adult testis (activity limited to primary spermatocytes and, possibly, spermatogonia). In 10 lymph node samples, we compared hTR expression with histology and with the TRAP assay results. A fibrotic tubercular node lacked both enzyme and hTR expression. Enzyme activity of varying degrees was present in all of the remaining nine samples. In histologically normal, tumour-free nodes, weak expression was consistently present in the germinal centres of secondary follicles, but in the other regions of the node hTR was absent or only weakly expressed in occasional single cells. High expression of hTR was present in tumour cells of all nodes containing metastases.

In our study, there was a correlation between the hTR expression and telomerase activity measurements. Although several nonmalignant cell types were negative for hTR expression, the major cells expressing hTR were activated $\mathrm{B}$ lymphocytes in lymph nodes and primary spermatocytes in testis. These findings are identical with the conclusions reached by others using the TRAP assay. ${ }^{27}{ }^{46}$

The present findings that hTR levels correlate well with telomerase activity in clinical samples seem to contradict the findings of Avillon et $a l^{32}$ who, using northern analysis, showed that some tumours with low hTR levels had high telomerase activity. There are many possible explanations for these apparent discrepant findings-for example, the TRAP assay is based on PCR and may reflect the amplification of a small subset of tumour cells depending on the efficiency of extraction. Thus, additional studies carefully comparing in situ hTR expression and telomerase activity with histopathological findings will be required to determine the diagnostic and prognostic usefulness of these new tumour markers.

In summary, this study showed that telomerase activity is present in almost all malignant and benign lymph nodes. However, the mean value of normalised telomerase activity in benign lymph nodes is lower than that of malignant lymph nodes. The germinal centres are the major (if not the sole) source of hTR in normal lymph nodes. In situ hybridisation, with or without measurements of telomerase enzyme activity, may facilitate the diagnosis of lymph node micrometastases in some patients.

Supported in part by Early Detection Research Network, National Cancer Institute, Bethesda, MD (N01-CN-45580-01) and the USAMR grant (17-94-J-4077), and Geron Corp. Menlo Park, CA.

1 Moyzis RK, Buckingham JM, Cram LS, Dani M, Deaven LL, Jones MD, et al. A highly conserved repetitive DNA sequence, (TTAGGG)n, present at the telomeres of human

2 Meyne J, Ratliff RL, Moyzis RK. Conservation of the human telomere sequence (TTAGGG)n among vertebrates. Proc Natl Acad Sci USA 1989;86:7049-53.

3 Klobutcher LA, Swanton MT, Donini P, Prescott DM. A gene-sized DNA molecules in four species of hypotrich have the same terminal sequence and an unusual 3 ' terminus. Proc Natl Acad Sci USA 1981;78:3015-9.
4 Makarov VL, Lejnine S, Bedoyan J, Langmore JP. Nucleosomal organization of telomere-specific chromatin in rat. Cell 1993;73:775-87.

5 Blackburn EH. Structure and function of telomeres. Nature 1991;350:569-73.

6 Watson JD. Origin of concatemeric T7 DNA. Nature New Biol 1972;239:197-201.

7 Olovnikov AM. A theory of marginotomy. The incomplete copying of template margin in enzymic synthesis of polynucleotides and biological significance of the phenomenon. F Theor Biol 1973;41:181-90.

8 Harley CB. Telomere loss: mitotic clock or genetic time bomb? Mutat Res 1991;256:271-82.

9 Wright WE, Shay JW. Telomere positional effects and the regulation of cellular senescence. Trends Genet 1992;8: 193-7.

10 Shay JW, Wright WE, Werbin H. Defining the molecula mechanisms of human cell immortalization. Biochim Biophys Acta 1991;1072:1-7.

11 Counter CM, Avilion AA, LeFeuvre CE, Stewart NG, Greider CW, Harley CB, et al. Telomere shortening associated with chromosome instability is arrested in immortal cells which express telomerase activity. EMBO 7 1992;11: 1921-9.

12 Morin GB. The human telomere terminal transferas enzyme is a ribonucleoprotein that synthesizes TTAGGG repeats. Cell 1989;59:521-9.

13 Counter CM, Hirte HW, Bacchetti S, Harley CB. Telomerase activity in human ovarian carcinoma. Proc Natl Acad Sc USA 1994;91:2900-4.

14 Kim NW, Piatyszek MA, Prowse KR, Harley CB, West MD, Ho PL, et al. Specific association of human telomerase activity with immortal cells and cancer. Science 1994;266: 2011-5.

15 Hiyama E, Hiyama K, Yokoyama T, Matsuura Y, Piatyszek MA, Shay JW. Correlating telomerase activity levels with human neuroblastoma outcomes. Nat Med 1995;1:249-55.

16 Hiyama $K$, Hiyama $E$, Ishioka $S$, Yamakido $M$, Inai $K$, Gazdar AF, et al. Telomerase activity in small-cell and non902 .

17 Chadeneau C, Hay K, Hirte HW, Gallinger S, Bacchetti S Telomerase activity associated with acquisition of malig nancy in human colorectal cancer. Cancer Res 1995;55: 2533-6.

18 Tahara H, Nakanishi T, Kitamoto M, Nakashio R, Shay JW, Tahara E, et al. Telomerase activity in human liver tissues: lar carcinomas. Cancer Res 1995;55:2734-6.

19 Hiyama E, Yokoyama T, Tatsumoto N, Hiyama K, Imamura $\mathrm{Y}$, Murakami Y, et al. Telomerase activity in gastric cancer. Cancer Res 1995;55:3258-62.

20 Langford LA, Piatyszek MA, Xu R, Schold S Jr, Shay JW. Telomerase activity in human brain tumours. Lancet 1995 346: $1267-8$

21 Hiyama K, Hirai Y, Kyoizumi S, Akiyama M, Hiyama E, Piatyszek MA, et al. Activation of telomerase in human lymphocytes and hematopoietic progenitor cells. $\mathcal{F}$ Immuno 1995;155:3711-5.

22 Chiu C, Dragowska W, Kim NW, Vaziri H, Yui J, Thomas TE, et al. Differential expression of telomerase activity in hematopoietic progenitors from adult human bone marrow. Stem Cells 1996;14:239-48.

23 Broccoli D, Young JW, de Lange T. Telomerase activity in normal and malignant hematopoietic cells. Proc Natl Acad Sci USA 1995;92:9082-6.

24 Counter CM, Gupta J, Harley CB, Leber B, Bacchetti S. Telomerase activity in normal leukocytes and in hematologic malignancies. Blood 1995;85:2315-20

25 Igarashi $\mathrm{H}$, Sakaguchi $\mathrm{N}$. Telomerase activity is induced by the stimulation to antigen receptor in human periphera lymphocytes. Biochem Biophys Res Commun 1996;219:64955.

26 Weng N, Levine BL, June CH, Hodes RJ. Regulated expression of telomerase activity in human $T$ lymphocyte
development and activation. $\mathcal{E}$ Exp Med 1996;183:2471-9.

27 Norrback K-F, Dahlenborg K, Carlsson R, Roos G. Telomerase activation in normal $B$ lymphocytes and nonerase activation in normal B lymphocyte
Hodgkin's lymphomas. Blood 1996;88:222-9.

28 Hiyama E, Hiyama K, Tatsumoto N, Shay JW, Yokoyama T Telomerase activity in human intestine. Int $\mathcal{F}$ Oncol 1996;9 453-8.

29 Taylor RS, Ramirez RD, Ogoshi M, Chaffins M, Piatyszek MA, Shay JW. Telomerase activity in malignant and nonmalignant skin conditions. $\mathcal{F}$ Invest Dermatol 1996;106: 759-65.

30 Harle-Bachor C, Boukamp P. Telomerase activity in the regenerative basal layer of the epidermis in human skin and in immortal and carcinoma-derived skin keratinocytes. Proc Natl Acad Sci USA 1996;93:6476-81.

31 Feng J, Funk WD, Wang SS, Weinrich SL, Avilion AA, Chiu $\mathrm{CP}$, et al. The RNA component of human telomerase. Science 1995;269:1236-41.

32 Avilion AA, Piatyszek MA, Gupta J, Shay JW, Bacchetti S, Greider CW. Human telomerase RNA and telomerase 1996;56:645-50.

33 Passlick B, Izbicki JR, Kubuschok B, Nathrath W, Thetter $\mathrm{O}$, Pichlmeier U, et al. Immunohistochemical assessment of individual tumor cells in lymph nodes of patients with nonsmall-cell lung cancer. $\mathcal{F}$ Clin Oncol 1994;12:1827-32.

34 Byrne J, Horgan PG, England S, Callaghan J, Given HF. A preliminary report on the usefulness of monoclonal antibodies to CA 15-3 and MCA in the detection of 
micrometastases in axillary lymph nodes draining primary breast carcinoma. Eur $\mathcal{F}$ Cancer 1992;28:658-60

35 Gunven P, Maruyama K, Okabayashi K, Sasako M, Kinoshita T. Non-ominous micrometastases of gastric cancer. $\mathrm{Br}$ f Surg 1991;78:352-4.

36 Cutait R, Alves VA, Lopes LC, Cutait DE, Borges JL, Singer $\mathrm{J}$, et al. Restaging of colorectal cancer based on the identification of lymph node micrometastases through immunoperoxidase staining of CEA and cytokeratins. Dis Colon Rectum 1991;34:917-20.

37 Hayashi N, Arakawa H, Nagase H, Yanagisawa A, Kato Y, Ohta $\mathrm{H}$, et al. Genetic diagnosis identifies occult lymph node metastases undetectable by the histopathological node metastases undetectable by the
method. Cancer Res 1994;54:3853-6.

38 Wang X, Heller R, VanVoorhis N, Cruse CW, Glass F, Fenske N, et al. Detection of submicroscopic lymph node metastases with polymerase chain reaction in patients with malignant melanoma. Ann Surg 1994;220:768-74.

39 Noguchi S, Aihara T, Nakamori S, Motomura K, Inaji H, Imaoka $\mathrm{S}$, et al. The detection of breast carcinoma micrometastases in axillary lymph nodes by means of reverse transcriptase-polymerase chain reaction. Cancer 1994;74:1595-600.

40 Schoenfeld A, Luqmani Y, Smith D, O'Reilly S, Shousha S, Sinnett HD, et al. Detection of breast cancer micrometa- stases in axillary lymph nodes by using polymerase chain reaction. Cancer Res 1994;54:2986-90.

41 Mori M, Mimori K, Inoue H, Barnard GF, Tsuji K, Nanbara S, et al. Detection of cancer micrometastases in lymph nodes by reverse transcriptase-polymerase chain reaction. Cancer Res 1995;55:3417-20.

42 Nilsson P, Mehle C, Remes K, Roos G. Telomerase activity in vivo in human malignant hematopoietic cells. Oncogene 1994;9:3043-8

43 Piatyszek MA, Kim NW, Weinrich SL, Hiyama K, Hiyama E, Wright WE, et al. Detection of telomerase activity in human cells and tumors by a telomeric repeat amplification protocol (TRAP). Methods Cell Sci 1995;17:1-15.

44 Wright WE, Shay JW, Piatyszek MA. Modifications of a telomeric repeat amplification protocol (TRAP) result in increased reliability, linearity and sensitivity. Nucleic Acids increased reliability,

45 Holt SE, Norton JC, Wright WE, Shay JW. Comparison of the telomeric repeat amplification protocol (TRAP) to the new TRAP-eze telomerase detection kit. Methods Cell Sci 1996;18:237-48.

46 Wright WE, Piatyszek MA, Rainey WE, Byrd W, Shay JW. Telomerase activity in human germline and embryonic tissues and cells. Dev Genet 1996;18:173-9. 